\title{
Detection of mycobacteria in coalho cheese sold in Northeastern Brazil
}

\section{Detecção de micobactérias em queijo de coalho comercializado no Nordeste do Brasil}

\begin{abstract}
Giovanni Brito Medeiros ${ }^{1}$; Onaldo Guedes Rodrigues²; Pirajá Saraiva Bezerra Neto Rosália Severo de Medeiros'²; Elaine Cristina Fernandes Baez Sartiं3; Flábio Ribeiro de Araújo ${ }^{3}$; Sérgio Santos de Azevedo ${ }^{2}$; Severino Silvano dos Santos Higino ${ }^{2^{*}}$
\end{abstract}

\section{Highlights}

Two samples (4\%) showed mycobacterial growth.

PCR was effective in detecting hsp65 of Mycobacterium spp. in cheese.

Phylogenetic analysis showed similarity with M. lehmannii and M. rutilum.

\section{Abstract}

The aim of the present study was to detect and identify Mycobaterium spp. in 50 samples of coalho cheese sold in the Northeast region of Brazil. Of the 50 analyzed samples, 35 were produced by the artisanal process, using raw milk, and 15 originated from industrialized establishments that pasteurize milk. Conventional and real-time nested PCR for the rv2807 gene of the M. tuberculosis complex was performed directly from the 50 analyzed samples. Samples of coalho cheese were grown simultaneously in Stonebrink medium, and conventional PCR was performed from the bacterial isolates with primers that flank differentiation region 4 (DR4), specific to M. bovis, mb400F. Bacterial isolates negative by PCR for RD4 were subjected to PCR for $h s p 65$ of Mycobacterium spp., with subsequent DNA sequencing. The cultures were negative for the $M$. tuberculosis complex, but two samples (4\%) from the artisanal process (with raw milk) exhibited identity with hsp65 of Mycobacterium lehmanii (Sequence ID: KY933786.1, identities:312/363 [86\%]); and Mycobacterium rutilum (sequence ID: LT629971.1, identities: 331/371 [89\%]), showing to be indicative environmental contamination. Non-tuberculous mycobacteria are emergent and ubiquitous microorganisms; therefore, they deserve greater attention in the cheese production chain, both in terms of Good Agricultural Practices (GAP) and food Good Manufacturing Practices (GMP).

Key words: Coalho cheese. Mycobacterium lehmanii. Mycobacterium ssp. Mycobacterium rutilum. NestedPCR.

1 Discentes do Curso de Doutorado do Programa de Pós-Graduação em Ciência Animal, PPGCA, Mestrado, Universidade Federal de Campina Grande, UFCG, Patos, PB, Brasil. E-mail: gbmvet@gmail.com; pirajamedvet@gmail.com

2 Profs. Drs., UFCG, Patos, PB, Brasil. E-mail: onaldoguedesrodrigues@yahoo.com.br; medeiros.rsm@gmail.com; sergio@vps.fmvz.usp.br; severino.silvano@professor.ufcg.edu.br

${ }_{3}$ Pesquisadores, Empresa Brasileira de Pesquisa Agropecuária, EMBRAPA Gado de Corte, Campo Grande, MS, Brasil. E-mail: elainebaez@hotmail.com; flabio.araujo@embrapa.br

* Author for correspondence

Received: June 08, 2020 - Approved: Oct. 19, 2020 


\section{Resumo}

O presente estudo teve como objetivo detectar e identificar Mycobaterium spp. em 50 amostras de queijo de coalho comercializados na região Nordeste do Brasil. Das 50 amostras analisadas, 35 foram produzidas pelo processo artesanal, com leite cru e 15 provenientes de estabelecimentos industrializados que realizam a pasteurização do leite. Nested-PCR convencional e em tempo real para o gene rv2807 do Complexo $M$. tuberculosis foi realizada diretamente das cinquenta amostras analisadas. Paralelamente, as amostras de queijo de coalho foram cultivadas em meio de Stonebrink e dos isolados bacterianos foi realizada PCR convencional com iniciadores que flanqueiam a região de diferenciação 4 (RD4), específica de M. bovis, mb400F. Os isolados bacterianos negativos na PCR para RD4 foram submetidos à PCR para hsp65 de Mycobacterium spp., com posterior sequenciamento do DNA. As culturas mostraram-se negativas para o Complexo M. tuberculosis, porém duas amostras oriundas do processo artesanal (com leite cru) (4\%) apresentaram identidade com hsp65 de Mycobacterium lehmanii (ID da sequência: KY933786.1, identidades: 312/363 [86\%]); e Mycobacterium rutilum (ID da sequência: LT629971.1, identidades: 331/371 [89\%]), apontando-se como indicativos de contaminação ambiental. As micobactérias-não-tuberculosas (MNT) são microrganismos emergentes e de natureza ubíqua. Devido a essas características merecem maior atenção na cadeia produtiva de queijos, tanto nas boas práticas agropecuárias (BPAs) quanto nas boas práticas de fabricação de alimentos (BPFs).

Palavras-chave: Queijo de coalho. Mycobacterium lehmanii. Mycobacterium ssp. Mycobacterium rutilum. Nested-PCR.

\section{Introduction}

At present, the genus Mycobacterium comprisesabout 170 species, including several important human pathogens and numerous non-tuberculous species. Although some are notable pathogens, such as $M$. tuberculosis, $M$. bovis and $M$. leprae, most are environmental organisms that act majorly as opportunistic infectious agents, usually in chronic patients (Tortoli, 2014).

Consumption of milk and its derivatives contaminated with $M$. bovis constitutes the main route of infection of zoonotic tuberculosis for humans. Despite this, NunesCosta, Alarico, Pretti Dalcolmo, CorreiaNeves and Empadinhas, (2016) emphasized the impact of non-tuberculous mycobacteria (NTM) on the morbidity and mortality of patients with malignant, autoimmune and immunosuppressed diseases, which have considerably increased in recent decades.

The consumption of artisanal coalho cheeses from street markets represents a risk to human health due to the possibility of transmission of potentially pathogenic NTM (Sarti et al., 2018). Some artisanal cheeses are typically produced with milk that does not undergo thermal treatment on small farms. In addition, artisanal production does not always meet good hygiene practices, which makes the consumption of this product a potential route of transmission of infectious agents. It is noteworthy that artisanal coalho cheese is a popular dairy product widely consumed in the Northeast region of Brazil that is produced from raw milk by adding coalho.

In view of the importance of coalho cheese consumption in northeastern Brazil and its possible participation in the epidemiological 
chain of foodborne diseases, this study was conducted to detect Mycobacterium spp. in this cheese type (artisanal and industrialized), sold in the sertão (hinterlands) of Rio Grande do Norte, northeast Brazil, through bacteriological cultivation and molecular detection.

Fifty samples of coalho cheese were collected in the retail market of the municipality of Caicó, which is located in the Central Mesoregion of the state of Rio Grande do Norte, northeast Brazil. Livestock and the dairy sector in this region are of fundamental importance for the agricultural and regional socio-spatial organization. In this region, cheese makers amount to 314 units that use $42 \%$ of all milk production for the manufacture of various types of products, such as butter, coalho cheese and ricotta cheese. Their annual production is $315 \mathrm{t}$ and they serve the consumer market in several states of the country (Agência de Desenvolvimento Sustentável de Seridó [ADESE], 2011).

Of the total of 50 samples of coalho cheese analyzed, 35 were produced by the artisanal process, using raw milk, and 15 originated from industrialized establishments that pasteurize milk. The samples were packed in plastic bags, frozen at $-20{ }^{\circ} \mathrm{C}$ and later transported in cooler boxes to the laboratory for further processing.

Two-gram aliquots of each cheese sample were macerated and homogenized. For the extraction of genetic material, the DNeasy Mericon Food kit (Qiagen, Hilden, Germany) was used, following the manufacturer's recommendations. The concentration of extracted DNA was determined using Qubit (Invitrogen, Waltham, USA), and its integrity in $1 \%$ agarose gel.

The nested-PCR for the rv2807 gene of the M. tuberculosis complex (MTC) was performed according to the protocol described by Araújo et al. (2014). Two sets of primers were designed, namely, external primers for amplification by conventional PCR, internal primers and probe for amplification by realtime PCR. The primer and probe sequences are shown in Table 1.

\section{Table 1}

Primers and probe used in Nested-PCR to detect the rv2807 gene of the Mycobacterium tuberculosis complex in coalho cheeses

Target site

rv2807

\section{DNA sequences $\left(5^{\prime} \rightarrow 3^{\prime}\right)$}

External F: GGCGGTGGCGGAGTTGAAGGCGATG

External R: GCCGCGAGCGAGTCTGGGCGATGTC

Probe: 6FAM CATCCACACCTGTTCG MGBNFQ

Internal F: CATTGCTGCGTAATTCGATCA Internal R: GACCTTGGGGCGCTCAT 
During the first stage, conventional PCR was performed using 10 pmol of each primer, $10 \mathrm{mM}$ dNTPs (Invitrogen, Waltham, USA), $2.5 \mu \mathrm{L}$ of $10 \times$ buffer (Sigma-Aldrich, St. Louis, USA), $1.25 \mathrm{U}$ of Taq DNA polymerase (Sigma-Aldrich, St. Louis, USA) and $100 \mathrm{ng}$ of DNAe, in a final reaction volume of $25 \mu \mathrm{L}$. Amplification conditions were $95^{\circ} \mathrm{C}$ for $4 \mathrm{~min}$, 35 cycles of $95^{\circ} \mathrm{C}$ for $90 \mathrm{~s}, 65^{\circ} \mathrm{C}$ for $30 \mathrm{~s}$, $72{ }^{\circ} \mathrm{C}$ for $45 \mathrm{~s}$ and a final extension at $72^{\circ} \mathrm{C}$ for $3 \mathrm{~min}$. Real-time PCR amplifications were performed in the second stage, using $5 \mathrm{pmol}$ of each primer (Applied Biosystems, Foster City, USA), 5 pmol of TaqMan probe (Applied Biosystems, USA), 6.25 $\mu \mathrm{L}$ of Master Mix PCR TaqMan (Applied Biosystems, Foster City, USA) and $3 \mu \mathrm{L}$ of the conventional PCR reaction, performed during the first stage, in a final reaction volume of $12.5 \mu \mathrm{L}$. The conditions for real-time PCR amplification were as follows: 95 ${ }^{\circ} \mathrm{C}$ for 10 min for initial denaturation, 35 cycles of denaturation at $95^{\circ} \mathrm{C}$ for $15 \mathrm{~s}$ and annealing/ extension at $62^{\circ} \mathrm{C}$ for $30 \mathrm{~s}$. All reactions were performed in a StepOne Plus thermocycler (Applied Biosystems, Foster City, USA), in duplicate, using template DNA from $M$. bovis AN5 as positive-reaction controls.

In parallel, $5 \mathrm{~g}$ of each coalho cheese sample were macerated with $5 \mathrm{~mL}$ of sterile $0.9 \% \mathrm{NaCl}$ solution (saline). Next, $40 \mathrm{~mL}$ of sterile $0.9 \%$ saline were added to the solution, which was followed by homogenization. From this mixture, $5 \mathrm{~mL}$ were separated and centrifuged for $15 \mathrm{~min}$ at $1,000 \mathrm{xg}$. The intermediate phase was discarded and $5 \mathrm{~mL}$ of sterile type-I water were added to the sediment, followed by shaking. Then, $5 \mathrm{~mL}$ of the suspension were transferred to a clean tube and $3 \mathrm{~mL}$ of sodium lauryl sulfate were added, followed by shaking; the tube containing the material was incubated at $37^{\circ} \mathrm{C}$ for $20 \mathrm{~min}$ and shaken at every 5 min. Subsequently, three drops of phenol red, five drops of $1 \mathrm{~N} \mathrm{HCl}$ and nine drops of $0.4 \%$ neutralizing solution were added. Eight drops were then deposited in a tube with Stonebrink medium, in duplicate, which were incubated at $37{ }^{\circ} \mathrm{C}$ without the use of $\mathrm{CO}_{2^{\prime}}$ for up to 90 days, and checked weekly for the growth of mycobacteria (Thoen, Himes, Jarnagin, \& Harrington, 1979).

The DNA extraction protocol for bacterial isolates obtained in Stonebrink medium was based on the thermolysis method, following De Medici et al. (2003). The DNA concentration was checked using a Qubit apparatus (Invitrogen, Waltham, USA) and its integrity by agarose gel with GelRed staining (Sigma-Aldrich, St. Louis, USA).

Once the DNA of the bacterial isolates was obtained, PCR was performed with primers that flank differentiation region 4 (RD4), specific to $M$. bovis, namely, mb400F, AACGCGACGACCTCATATTC and mb400R: AAGGCGAACAGATTCAGCAT, which amplify a 400-bp fragment. The reaction was carried out using 10 pmol of each primer, $10 \mathrm{mM}$ dNTPs (Invitrogen, Waltham, USA), $2.5 \mu \mathrm{L}$ of $10 \times$ buffer (Sigma-Aldrich, St. Louis, USA), 1.25 U of Taq DNA polymerase (Sigma-Aldrich, St. Louis, USA) and 100 ng of DNA, in a final reaction volume of $25 \mu \mathrm{L}$. The PCR amplification conditions were $94^{\circ} \mathrm{C}$ for $5 \mathrm{~min}$ and 35 cycles at $94^{\circ} \mathrm{C}$ for $30 \mathrm{~s}, 56^{\circ} \mathrm{C}$ for $30 \mathrm{~s}$ and $72^{\circ} \mathrm{C}$ for 35 $\mathrm{S}$, with a final extension at $72^{\circ} \mathrm{C}$ for $3 \mathrm{~min}$.

Bacterial isolates negative by $\mathrm{PCR}$ for RD4 were subjected to PCR for hsp65 of Mycobacterium spp., for subsequent DNA sequencing. For this, primers Tb11: ACCAACGATGGTGTGTCCAT and Tb12: 
CTTGTCGAACCGCATACCCT were used for Mycobacterium spp., following Telenti et al. (1993). The reaction was performed using 10 pmoL of each primer, $10 \mathrm{mM}$ dNTPs (Invitrogen, Waltham, USA), $2.5 \mu \mathrm{L}$ of $10 \times$ buffer (SigmaAldrich, St. Louis, USA), $1.25 \mathrm{U}$ of Taq DNA polymerase (Sigma-Aldrich, St. Louis, USA) and $100 \mathrm{ng}$ of DNA, in a reaction volume of $25 \mu \mathrm{L}$. The conditions for PCR amplification were as follows: 45 cycles of denaturation for 60 s at 94 ${ }^{\circ} \mathrm{C}$, annealing for $60 \mathrm{~s}$ at $60^{\circ} \mathrm{C}$ and extension at $72^{\circ} \mathrm{C}$, followed by a 10 -min extension at $72^{\circ} \mathrm{C}$.

Subsequently, the PCR products were purified using ExoSAP (ThermoFischer, Waltham, USA) and sequenced in duplicate using the BigDye Terminator Cycle Sequencing Kit (version 3.1, Applied Biosystems, Foster City, USA). The resulting consensus DNA sequences were subjected to identity search using Blastn (NCBI).

The coalho cheese samples were negative by nested-PCR for MTC (rv2807 gene). However, two samples (4\%) from the artisanal process (with raw milk) showed identity with hsp65 of Mycobacterium lehmanii (sequence ID: KY933786.1, identities: 312/363 [86\%]); and Mycobacterium rutilum (sequence ID: LT629971.1, identities: 331/371 [89\%]).

In Brazil, research investigating the presence of mycobacteria in coalho cheese is still incipient. In a study conducted by Rocha (2013) on coalho cheeses produced in the state of Piauí, molecular evidence of $M$. bovis was found in $10 \%$ of the analyzed material. This generated an alert to the authorities about the need for further research aiming at the search of this pathogen in humans, animals and food, as well as studies aiming at uniformity in the artisanal cheese production process, to ensure the safety of this product.
Non-tuberculous mycobacteria are usually found in water, soil and dust. Until not long ago, NTM were not associated with pathogens in humans, but, recently, with the advent of molecular diagnosis, they have been constantly mentioned in medical research articles (Falkinham, 2013). Recent molecular biology studies corroborate this information, presenting new species, e.g. Nouioui et al. (2017), who proposed the creation of two new species of fast-growing mycobacteria: $M$. lehmannii sp. nov. and $M$. neumannii sp. nov., respectively.

Although most studies seek to detect M. bovis and M. avium subsp. paratuberculosis (MAP) in cheeses produced with raw milk, given the zoonotic potential of these agents, recent studies have aspired to detect other mycobacteria. This can be seen in the study of Sarti et al. (2018), who analyzed coalho cheeses sold in the state of Paraíba, Brazil, and detected contamination of $5 \%(n=100)$ with NTM (M. fortuitum, M. novocastrense).

Currently, NTM are emerging microorganisms, and due to their ubiquitous nature, they deserve special attention, especially in the production of dairy products. The identification of NTM in coalho cheeses makes greater sanitary control of this product necessary in producing regions in order to ensure its quality.

\section{Acknowledgments}

Thanks are due to Embrapa Beef Cattle, Campo Grande - MS, for the infrastructure provided for the execution of this study; and, in particular, to Gisele Olivas de Campos Leguizamon for technical support. 


\section{Conflict of interests}

The authors declare no conflict of interest.

\section{Authors' contributions}

All authors contributed equally to the conceptualization and writing of the manuscript. All authors critically reviewed the manuscript and approved the final version.

\section{References}

Agência de Desenvolvimento Sustentável de Seridó (2011). Diagnóstico da bacia leiteira do território Seridó. Caicó-RN: Colegiado territorial do Seridó. Recuperado de http:// adeseserido.blogspot.com/2012/08/ adese-disponibiliza-download-do.html

Araújo, C. P., Osório, A. L. A. R., Jorge, K. S. G., Ramos, C. A. N., Souza, A. F., Fo., Vidal, C. E. S.,... Araújo, F. R. (2014). Detection of Mycobacterium bovis in bovine and bubaline tissues using nested-PCR for TbD1'. PLOS ONE, 9(3), 6. doi: 10.1371/ journal.pone.0091023 Retrieved from https://www.ncbi.nlm.nih.gov/pubm ed/24618787

De Medici, D., Croci, G., Delibato, E., Di Pasquale, S., Filetici, E., \& Toti, L. (2003). Evaluation of DNA extraction methods for use in combination with SYBR green i realtime PCR to detect Salmonella enterica serotype Enteritidis in poultry. Applied and Environmental Microbiology, 69(6), 3456-3461. doi: 10.11 28/AEM.69.6.34563461.2003 Retrieved from https://aem. asm.org/content/69/6/3456

Falkinham, J. O. (2013). Ecology of nontuberculous mycobacteria where do human infections come from? Seminars in Respiratory and Critical Care Medicine, 34(1), 95-102. doi: 10.1055/s-00331333568 Retrieved from https://www. thieme-connect.de/products/ejournals/ abstract/10.1055/s-0033-1333568

Nouioui, I., Sangal, V., Carro, L., Teramoto, K., Jando,M.,Montero-Calasanz,M.D.C., Klenk, H. P. (2017). Two novel species of rapidly growing mycobacteria: Mycobacterium lehmannii sp. nov. and Mycobacterium neumannii sp. nov. International Journal of Systematic and Evolutionary Microbiology, 67(12), 4848-4955. doi: 10.1099/ijsem.0.002350 Retrieved from https://www.microbiologyresearch. org/content/journal/ijsem/10.1099/ ijsem.0.002350\#tab2

Nunes-Costa, D., Alarico, S., Pretti Dalcolmo, M., Correia-Neves, M., \& Empadinhas, N. (2016). The looming tide of nontuberculous mycobacterial infections in Portugal and Brazil. Tuberculosis, 96(1), 107-119. doi: 10.1016/j.tube.2015.09.006 Retrieved from https://www.sciencedirect. com/science/article/abs/pii/S1472 979215300627

Rocha, B. B. (2013). Ocorrência de Mycobacteirum bovis em queijos coalho artesanais e fatores associados ao consumo de leite e derivados lácteos informais. Dissertação de mestrado, Universidade Federal de Viçosa, Viçosa, MG, Brasil. Recuperado de http://locus.ufv. br/handle/123456789/5161

Sarti, E. C. F. B., Rodrigues, R. A., Duarte, L. F. C., Bacanelli, G. M., Lilenbaum, W., \& Araújo F. R. (2018). Detection of potentially pathogenic non-tuberculous mycobacteria in artisanal coalho cheese from the State of Paraiba, Northeast Brazil. Mycobacterial Diseases, 8(3), 1000266. doi: $\quad 10.4172 / 2161-1068.1000266$ 
Retrieved from https://www.longdom. org/open-access/detection-ofpotentially-pathogenic-nontuberculousmycobacteria-inartisanal-coalho-cheesefrom-the-state-of-paraiba-northeastbraz-2161-1068-1000266.pdf

Telenti, A. Marchesi, F., Balz, M., Bally, F., Böttger, C. E., \& Bodmer T. (1993). Rapid identification of mycobacteria to the species level by polymerase chain reaction and restriction enzyme analysis. Journal of Clinical Microbiology, 31(2), 175-178. doi: 0095-1137/93/02017504\$02.00/0 Retrieved from https:// jcm. asm.org/content/31/2/175.short
Thoen, C. O., Himes, E. M., Jarnagin, J. L., \& Harrington, R., Jr. (1979). Comparison of four culture media for isolation of Mycobacterium avium complex from porcine tissues. Journal of Clinical Microbiology, 9(2), 194-196. doi: 00951137/79/02-0194/03\$02.00/0 Retrieved from https://jcm.asm.org/content/jcm/9/ 2/194.full.pdf

Tortoli, E. (2014). Microbiological features and clinical relevance of new species of the genus Mycobacterium. Clinical Microbiology Reviews, 27(4), 727-752. doi: 10.1128/CMR.00035-14 Retrieved from https:// pubmed.ncbi.nlm.nih. gov/25278573/ 
